\title{
Retinol-Binding Protein 4 Expression in Visceral and Subcutaneous Fat in Human Obesity
}

\author{
M. BAJZOVÁ*1,2 M. KOVÁČIKOVÁ*1,2,4, M. VÍTKOVÁ ${ }^{1,2,3,4}$, E. KLIMČÁKOVÁ ${ }^{1,2,3,4}$, \\ J. POLÁK ${ }^{1,2,4}$, Z. KOVÁČOVÁ ${ }^{1,2,4}$, N. VIGUERIE ${ }^{1,3,7}$, T. VEDRAL $^{5}$, L. MIKULÁŠEK ${ }^{5}$, \\ P. ŠRÁMKOVÁ ${ }^{6}$, A. SRP ${ }^{5}$, J. HEJNOVÁ ${ }^{1,2}$, D. LANGIN ${ }^{1,3,7,8}$, V. ŠTICH ${ }^{1,2}$ \\ * These authors contributed equally to the work.
}

${ }^{1}$ French-Czech Laboratory for Clinical Research on Obesity, ${ }^{2}$ Department of Sports Medicine, ${ }^{4}$ Division of Cell and Molecular Biology, Third Faculty of Medicine, Charles University, Prague, Czech Republic, ${ }^{3}$ INSERM, U858, Obesity Research Laboratory, Rangueil Institute of Molecular Medicine, Toulouse, France ${ }^{5}$ Department of Surgery, Department of Gynecology and Obstetrics, Department of Radiology, Faculty Hospital Královské Vinohrady, Prague, ${ }^{6}$ ISCARE, Prague, Czech Republic, ${ }^{7}$ Paul Sabatier University, Louis Bugnard Institute, IFR31, ${ }^{8} \mathrm{CHU}$ de Toulouse, Biochemistry Laboratory, Biology Institute of Purpan, Toulouse, France

Received August 17, 2007

Accepted October 9, 2007

On-line November 30, 2007

\section{Summary}

Retinol binding protein 4 (RBP4) is a novel adipokine which might be involved in the development of insulin resistance. The aim of the study was to investigate the expression of RBP4 mRNA in subcutaneous and visceral fat depots and the relationship between RBP4 plasma and mRNA levels relative to indices of adiposity and insulin resistance. In 59 Caucasian women (BMI 20 to $49 \mathrm{~kg} / \mathrm{m}^{2}$ ) paired samples of subcutaneous and visceral fat were obtained for RBP4, leptin and GLUT 4 mRNA analysis using reverse transcription-quantitative PCR. Euglycemic hyperinsulinemic clamp and computed tomography scans were performed. RBP4 mRNA levels as well as GLUT 4 mRNA and leptin mRNA levels were lower $(\mathrm{P}<0.001, \mathrm{P}<0.01$ and $\mathrm{P}<0.001$, respectively) in visceral compared to subcutaneous fat. No differences were found in RBP4 mRNA expression in the two fat depots or in RBP4 plasma levels between subgroups of non-obese subjects $(n=26)$, obese subjects without metabolic syndrome $(n=17)$ and with metabolic syndrome $(n=16)$. No correlations between RBP4 mRNA or plasma levels relative to adiposity, glucose disposal rate and GLUT 4 mRNA expression in adipose tissue were found. There was a weak positive correlation between plasma RBP4 and plasma triglycerides $(r=0.30, p<0.05)$ and between plasma RBP4 and blood glucose $(r=0.26, p<0.05)$. Regardless of the state of adiposity or insulin resistance, RBP4 expression in humans was lower in visceral than in subcutaneous fat. We found no direct relationship between either RBP4 mRNA or its plasma levels and the adiposity or insulin resistance.

\section{Key words}

Obesity • Insulin resistance • Visceral and subcutaneous adipose tissue $\bullet$ Retinol-binding protein 4

\section{Corresponding author}

V. Štich, Department of Sports Medicine, Third Faculty of Medicine, Charles University, Ruská 87, 10000 Prague 10, Czech Republic. Fax + 420267102263. E-mail: vladimir.stich@lf3.cuni.cz

\section{Introduction}

Obesity is one of the principal causes of insulin resistance and a significant risk factor for type 2 diabetes. Excess adipose tissue is associated with the release of several molecules having paracrine and/or endocrine activity capable of contributing to the development of insulin resistance. A recently characterized potential candidate is retinol binding protein 4 (RBP4) (Yang et al. 2005). Adipose tissue RBP4 mRNA expression and circulating plasma levels have been shown to be increased in several mouse models of insulin resistance. 
Overexpression of RBP4 or injection of recombinant RBP4 induces insulin resistance in mice, whereas pharmacologically decreased serum levels of RBP4 improved insulin sensitivity in mice maintained on high fat diets (Yang et al. 2005). Selective genetic knockout of the insulin-stimulated glucose transporter (GLUT 4) in adipocytes results in impaired whole-body insulin sensitivity, an effect thought to be mediated by RBP4 (Abel et al. 2001). In humans, elevated RBP4 levels have been reported in subjects with insulin resistance and type 2 diabetes (Yang et al. 2005, Cho et al. 2006, Graham et al. 2006). RBP4 is produced by hepatocytes but it is also produced in rat (Tsutsumi et al. 1992) and human (Janke et al. 2006) adipocytes. In a previous study we have shown that RPB4 is secreted by human adipose tissue explants and that it is expressed almost exclusively in mature adipocytes (the expression in stromavascular fraction of adipose tissue being negligible) (Vitkova et al. 2007).

Recently, mRNA expression of RBP4 has been found to be down-regulated in subcutaneous adipose tissue of obese women (Janke et al. 2006) and upregulated in a group of ten women with polycystic ovary syndrome when compared to lean controls (Tan et al. 2007). Moreover, during a multiple phase dietary intervention, changes in RBP4 mRNA were not related to the improvement in insulin sensitivity (Janke et al. 2006). No relationship between plasma RBP4 levels and RBP4 mRNA expression in subcutaneous adipose tissue has been found (Janke et al. 2006). These findings might suggest a possible role of visceral fat depot in the RBP4 production. Therefore, we investigated RBP4 mRNA expression in paired samples of subcutaneous and visceral adipose tissue in a cohort of patients with a wide range of BMI and visceral fat mass, as evaluated by computed tomography, and diverse insulin sensitivity. This cohort was also used to study the relationship between plasma RBP4 and indices of adiposity and between plasma RBP4 and insulin resistance.

\section{Methods}

\section{Subjects}

Fifty-nine Caucasian women (age 21 to 66 years, BMI 19.6 to $48.5 \mathrm{~kg} / \mathrm{m}^{2}$ ) scheduled to have abdominal surgery (laparoscopic or laparotomic cholecystectomy, hysterectomy and gastric banding) were recruited for the study in collaboration with the Departments of Surgery and Gynecology at Královské Vinohrady Faculty
Hospital in Prague. Subjects with following conditions were excluded from the study: malignancy, inflammatory conditions (based on clinical and laboratory findings), congestive heart failure, known coronary heart disease, known endocrinopathies, chronic liver or kidney disease and psychiatric disorders. All the subjects were weightstable, i.e. their body weight fluctuations were less than $2 \%$ during the preceding 3 months. The study was approved by the Ethical Committee of the Third Faculty of Medicine, Charles University, Prague. A written informed consent was obtained from each subject before the start of the study.

\section{Study protocol}

Prior to their surgery (7-14 days), each participant was examined after an overnight fast at $8.00 \mathrm{~h}$.

\section{Anthropometric measurements}

Body height, weight and waist and hip circumference were measured and body composition was evaluated using bioelectrical impedance (QuadScan 4000, Bodystat, Douglas, British Isles). Visceral fat area and the relative ratio of intra-abdominal visceral fat to the subcutaneous fat area were calculated using computed tomography scans at the level L4-5 as previously described (Fujioka et al. 1987).

\section{Euglycemic-hyperinsulinemic clamp}

Insulin sensitivity was assessed using euglycemic-hyperinsulinemic clamp performed according to DeFronzo et al. (1979). The dose of insulin was $40 \mathrm{mU} / \mathrm{min} / \mathrm{m}^{2}$ body surface. The rate of glucose disposal was defined as the glucose infusion rate during the stable period of $30 \mathrm{~min}$ during the second hour of the clamp and was related to body weight $(\mathrm{M}-\mathrm{mg} / \mathrm{min} / \mathrm{kg})$. Blood samples for determination of baseline values were obtained before the clamp.

\section{Adipose tissue samples}

During the scheduled surgical procedure, paired samples of visceral (omental) and subcutaneous adipose tissue were obtained and processed immediately.

\section{Analytical methods}

Blood glucose, triglycerides, total and HDL cholesterol and plasma insulin were measured using standard procedures. Plasma RBP 4 concentrations were determined using sandwich ELISA (Immunodiagnostik AG, Behsheim, Germany). This kit is identical in 
protocol and reagent composition with the ELISA kit from ALPCO Diagnostics (USA) tested by Graham et al. (2007). Plasma samples were diluted so that the absorbance was in the middle of the range of linearity for the assay (intraassay CV was $5 \%$ and interassay $\mathrm{CV}$ was $9 \%$, within-run CV for RBP-4 was $2.7 \%$ ).

\section{RNA analysis}

Adipose tissue samples were washed, homogenized in RLT lysis buffer (Qiagen, Courtaboeuf, France) and stored at $-80{ }^{\circ} \mathrm{C}$ until analyzed. Total RNA extraction was done with a RNeasy Mini kit (Qiagen, Courtaboeuf, France). Reverse transcription was performed with $1 \mu \mathrm{g}$ of total RNA using random hexamers as primers and Superscript II reverse transcriptase (Invitrogen, Cergy Pontoise, France). Realtime quantitative PCR (qPCR) was performed with a Taqman probe-based RBP4 gene expression assay using a ABI PRISM 7000 Sequence Detection System (Applied Biosystems, Foster City, CA, USA). Primers and TaqMan probes for RBP4, leptin and GLUT4 were obtained from Applied Biosystems. Each sample was measured in duplicate and $10 \mathrm{ng}$ of cDNA was used as a template for real-time qPCR. If the difference between duplicate samples exceeded $0.5 \mathrm{Ct}$, then qPCR was repeated. $18 \mathrm{~S}$ ribosomal RNA was used as a control to normalize gene expression (Ribosomal RNA Control TaqMan Assay kit, Applied Biosystems). Results are expressed as $2^{-\Delta \mathrm{Ct}}$ values.

\section{Statistical analysis}

The data were analyzed using SPSS 13.0 statistical software. The data are reported as means \pm SEM. Before statistical analysis, non-normally distributed parameters were logarithmically transformed. Differences between visceral and subcutaneous fat were assessed using the Student t-test. A one way ANOVA was used for group comparisons with a Bonferoni post hoc analysis. The Pearson's correlation coefficient was calculated to quantify univariate associations.

\section{Results}

\section{Stratification of the entire study group}

The entire group of subjects consisted of 26 nonobese and 33 obese subjects. The obese group was further stratified according to the presence $(n=17)$ or absence $(n=16)$ of the metabolic syndrome evaluated according to the International Diabetes Federation criteria (Alberti et al. 2005). Relevant anthropometric and metabolic characteristics of the three groups are given in Table 1. Obese subjects with metabolic syndrome had a higher relative amount of visceral fat (when related to the subcutaneous depot) and a higher plasma triglycerides concentration compared with obese without metabolic syndrome. In fact, for these two variables, the latter group did not differ from non-obese subjects. The glucose disposal rate was lower in obese patients than in lean subjects.

\section{RBP 4 expression in visceral and subcutaneous fat}

RBP4 mRNA levels in visceral adipose tissue were markedly lower than those in the subcutaneous adipose tissue in each of the three subgroups (Table 2) as well as for the entire group ( $2.0 \pm 0.2$ vs. $8.0 \pm 0.7$ arbitrary units, $\mathrm{p}<0.001)$. There were no differences in RBP4 mRNA levels in either visceral or subcutaneous fat between the three groups. For the entire group, there was a significant correlation between RBP4 mRNA levels in visceral and subcutaneous fat $(r=0.347, p<0.05)$.

GLUT 4 and leptin expression in visceral and subcutaneous fat

In the three subgroups, leptin mRNA expression was lower in visceral compared to subcutaneous fat. GLUT 4 mRNA levels were lower in visceral fat, the difference, however, being significant only in obese subjects without metabolic syndrome (Table 2).

\section{Plasma RBP4 concentrations}

No differences in plasma RBP4 concentrations were seen between the three subgroups (Table 1). Additionally, no significant correlations between the plasma RBP4 levels and either visceral or subcutaneous mRNA levels were found for the entire group or each of the subgroups (data not shown).

\section{Relationship between RBP4 indices and anthropometric} or metabolic variables

For the entire study group, none of the RBP4 indices, i.e. plasma RBP4, subcutaneous mRNA and visceral mRNA levels, correlated with BMI, fat mass, waist circumference or with the CT-evaluated area of visceral or subcutaneous fat (Table 3). Similarly, none of the RBP4 indices correlated with glucose disposal rate, fasting plasma insulin, plasma LDL or HDL cholesterol. However, plasma RBP4 showed a weak correlation with plasma triglycerides and blood glucose (Fig. 1). 
Table 1. Anthropometric and metabolic characteristics in non-obese patients (nonOB) and obese patients without (OB) and with (MS) metabolic syndrome.

\begin{tabular}{|c|c|c|c|}
\hline Group & $\operatorname{nonOB}(n=26)$ & OB $(n=17)$ & $\operatorname{MS}(n=16)$ \\
\hline Age (years) & $40.2 \pm 2.3$ & $41.6 \pm 2.4$ & $49.4 \pm 2.7$ \\
\hline$B M I\left(\mathrm{~kg} / \mathrm{m}^{2}\right)$ & $24.5 \pm 0.73$ & $37.1 \pm 1.4^{\mathrm{a}}$ & $33.9 \pm 1.2^{b}$ \\
\hline Waist (cm) & $83.3 \pm 2.1$ & $108.8 \pm 2.7^{\mathrm{a}}$ & $107.3 \pm 2.6^{b}$ \\
\hline Fat mass (\%) & $30.2 \pm 1.38$ & $45.3 \pm 1.16^{\mathrm{a}}$ & $41.9 \pm 1.39^{b}$ \\
\hline Visceral fat $\left(\mathrm{cm}^{2}\right)$ & $74.1 \pm 10.1$ & $121.4 \pm 9.8^{\mathrm{a}}$ & $156.2 \pm 12.8^{b}$ \\
\hline Subcutaneous fat $\left(\mathrm{cm}^{2}\right)$ & $250.2 \pm 25.3$ & $510.5 \pm 30.3^{\mathrm{a}}$ & $409.2 \pm 29.9^{\mathrm{b}, \mathrm{c}}$ \\
\hline Visceral /subcutaneous fat & $0.28 \pm 0.11$ & $0.24 \pm 0.07$ & $0.42 \pm 0.18^{\mathrm{b}, \mathrm{c}}$ \\
\hline HDL-cholesterol (mmol/l) & $1.48 \pm 0.06$ & $1.40 \pm 0.07$ & $1.25 \pm 0.05^{\mathrm{b}}$ \\
\hline LDL-cholesterol (mmol/l) & $3.13 \pm 0.16$ & $2.85 \pm 0.27$ & $3.0 \pm 0.33$ \\
\hline Triglycerides (mmol/l) & $1.01 \pm 0.12$ & $1.22 \pm 0.09$ & $2.36 \pm 0.36^{\mathrm{b}, \mathrm{c}}$ \\
\hline Blood glucose ( $\mathrm{mmol} / \mathrm{l})$ & $4.78 \pm 0.08$ & $5.38 \pm 0.12^{\mathrm{a}}$ & $6.22 \pm 0.44^{b}$ \\
\hline Insulin (mmol/l) & $5.88 \pm 0.54$ & $10.6 \pm 1.7^{\mathrm{a}}$ & $13.3 \pm 1.5^{\mathrm{b}}$ \\
\hline Glucose disposal rate - $M\left(\mathrm{mg} \cdot \mathrm{kg}^{-1} \cdot \mathrm{min}^{-1}\right)$ & $6.17 \pm 0.44$ & $3.80 \pm 0.34^{\mathrm{a}}$ & $2.81 \pm 0.33^{b}$ \\
\hline RBP4 plasma $(\mathrm{mg} / \mathrm{l})$ & $27.8 \pm 1.5$ & $26.0 \pm 1.6$ & $29.2 \pm 1.8$ \\
\hline
\end{tabular}

Values are means \pm S.E.M. Groups are compared by one way ANOVA with Bonferroni's multiple t-test post-hoc analysis: ${ }^{a} p<0.05$ OB vs. nonOB, ${ }^{b} p<0.05$ MS vs. nonOB, ${ }^{c} p<0.05$ MS vs. OB.

Table 2. Relationships of RBP4, GLUT 4 and leptin mRNA expression in visceral (VAT) and subcutaneous (SCAT) adipose tissue in nonobese (nonOB), obese without (OB) and obese with (MS) metabolic syndrome.

\begin{tabular}{lcccccc}
\hline \multirow{2}{*}{ Group } & \multicolumn{2}{c}{ nonOB $(\mathbf{n}=\mathbf{2 6})$} & \multicolumn{2}{c}{ OB $(\mathbf{n}=\mathbf{1 7})$} & \multicolumn{2}{c}{ MS (n= 16) } \\
& VAT & SCAT & VAT & SCAT & VAT & SCAT \\
\hline$m R N A$ RBP4 & $2.8 \pm 0.4^{\mathrm{d}}$ & $8.9 \pm 1.3$ & $2.5 \pm 0.3^{\mathrm{d}}$ & $9.7 \pm 1.3$ & $1.8 \pm 0.3^{\mathrm{d}}$ & $5.7 \pm 0.9$ \\
$m R N A$ GLUT 4 & $5.4 \pm 1.07$ & $7.7 \pm 1.1$ & $2.9 \pm 0.5^{\mathrm{e}}$ & $6.0 \pm 1.1$ & $2.7 \pm 0.8$ & $3.4 \pm 0.8$ \\
$m R N$ A leptin & $8.7 \pm 1.9^{\mathrm{d}}$ & $30.4 \pm 3.8$ & $9.7 \pm 1.5^{\mathrm{d}}$ & $65.1 \pm 9.7$ & $25.1 \pm 6.3^{\mathrm{e}}$ & $43.6 \pm 7.7$ \\
\hline
\end{tabular}

Values are means \pm S.E.M. mRNA are expressed in arbitrary units $(\mathrm{AU}) \times 10^{-4} 4{ }^{\mathrm{d}} \mathrm{mRNA}$ expression in visceral vs. subcutaneous adipose tissue, $p<0.001,{ }^{e}$ mRNA expression in visceral vs. subcutaneous adipose tissue, $p<0.05$

\section{Relationship between RBP4 and GLUT 4 expressions}

In the entire study group, GLUT 4 mRNA levels in visceral fat correlated with RBP4 mRNA levels in visceral as well as subcutaneous fat $(\mathrm{r}=0.447, \mathrm{p}<0.01)$ while no such correlations were found for GLUT4 in subcutaneous fat.

\section{Discussion}

Retinol binding protein 4 has been proposed as an adipokine involved in the regulation of systemic glucose metabolism and pathogenesis of insulin resistance (Yang et al. 2005, Graham et al. 2006, Cho et al. 2006, Janke et al. 2006). The expression of RBP4 has been demonstrated in subcutaneous and, recently, in visceral adipose tissue in humans (Tan et al. 2007). In our previous study (Vitkova et al. 2007) it was shown that 1) RBP4 is expressed mainly in adipocytes and the expression in stromavascular fraction of adipose tissue is negligible and 2) RBP4 is secreted from human adipose tissue explants. In the present study, we demonstrated that, in a group of women with a wide range of adiposity and insulin resistance, RBP4 expression in visceral fat was markedly lower than in subcutaneous fat. This finding was independent of BMI, amount of visceral or subcutaneous fat or the presence of metabolic syndrome in the examined subjects. In fact, no differences between the expression of RBP4 in either visceral or subcutaneous fat were found between the three subgroups stratified according to adiposity and presence of indices of 
Table 3. Correlations of mRNA expression in subcutaneous (SCAT) and visceral (VAT) fat and of plasma RBP4 levels with selected anthropometric and metabolic variables in the entire group of subjects $(n=59)$.

\begin{tabular}{lccc}
\hline & $\begin{array}{c}\text { logRBP4 } \\
\text { plasma }\end{array}$ & $\begin{array}{c}\text { mRNA } \\
\text { RBP4 } \\
\text { SCAT }\end{array}$ & $\begin{array}{c}\text { mRNA } \\
\text { RBP4 } \\
\text { VAT }\end{array}$ \\
\hline $\begin{array}{l}\text { BMI } \\
\text { Waist (cm) }\end{array}$ & 0.01 & 0.037 & -0.081 \\
$\begin{array}{l}\text { Fat mass }(k g) \\
\text { Visceral fat } \\
\left.\text { (cm }^{2}\right)\end{array}$ & 0.039 & -0.048 & -0.048 \\
$\begin{array}{l}\text { Subcutaneous } \\
\left.\text { fat (cm }{ }^{2}\right)\end{array}$ & 0.116 & 0.056 & -0.005 \\
$\begin{array}{l}\text { Triglycerides } \\
\text { (mmol/l) }\end{array}$ & -0.01 & -0.036 & 0.154 \\
$\begin{array}{l}\text { HDL-cholesterol } \\
\text { (mmol/l) }\end{array}$ & $0.298^{\mathrm{a}}$ & 0.015 & -0.166 \\
$\begin{array}{l}\text { Blood glucose } \\
\text { Glucose } \\
\text { disposal rate }\end{array}$ & -0.106 & 0.024 & -0.056 \\
\hline
\end{tabular}

Data are Pearson's correlation coefficient $r,{ }^{a} p<0.05$

metabolic syndrome. Our results suggest that, in humans, visceral adipose tissue is not significantly involved in RBP4-mediated effects on carbohydrate metabolism and /or insulin action or, alternatively, RBP4 does not appear to be a link between the visceral fat and insulin resistance.

Although RBP4 is expressed predominantly in mature adipocytes, the differences in gene expression between the two fat depots might be influenced by a higher macrophages infiltration in visceral compared with subcutaneous depots (Cancello et al. 2006). It may be hypothesized that the higher down-regulation of RBP4 in visceral fat by some of the macrophage-derived signals, such as TNF- $\alpha$ (Sell et al. 2007), might contribute to the lower RBP-4 expression in visceral fat. Alternatively, the effect of a higher "dilution“ of adipocytes due to higher proportion of non-fat cells in visceral fat could be considered.

According to recent results showing the relationship between gene expression in adipocytes and adipose cell size (Skurk et al. 2007) it could be speculated that the difference in RBP4 expression between the visceral and subcutaneous fat depots might be associated with differences in adipocyte size in the two depots. The adipose cell size was not measured in the present study, although recent studies did not find major differences in
A

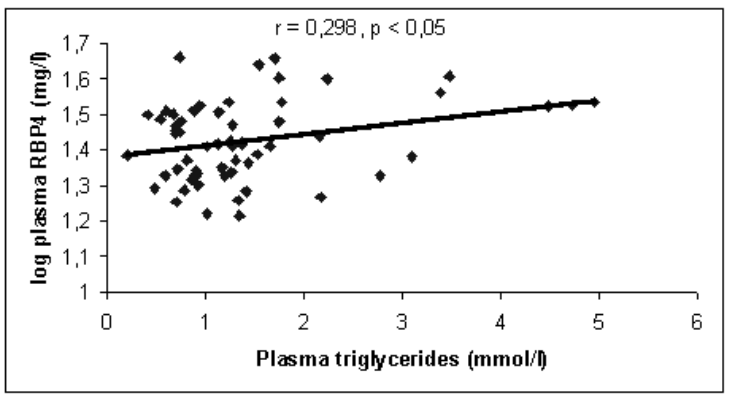

B

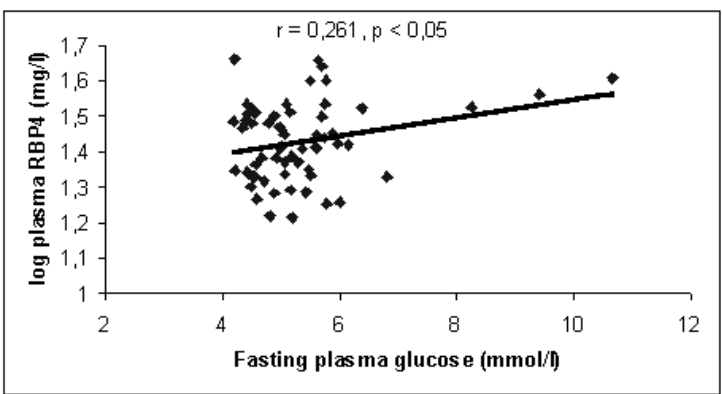

c

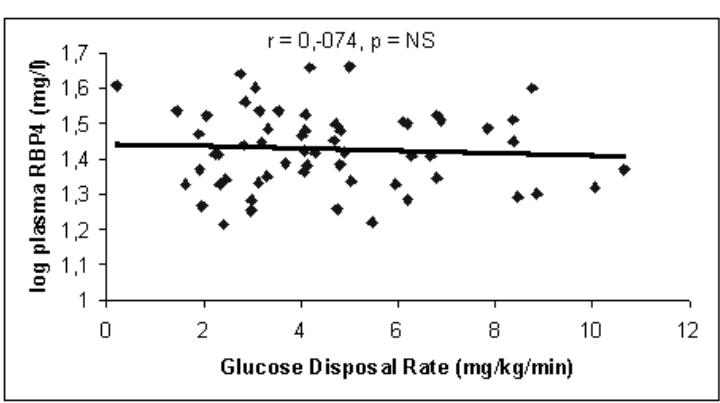

Fig. 1. Correlation between plasma RBP4 concentration (data were log transformed to achieve normal distribution), plasma triglycerides (A), fasting plasma glucose (B) and glucose disposal rate $(C)$ in the entire group of subjects.

the size of adipocytes from visceral and subcutaneous depots (Winkler et al. 2003, Garaulet et al. 2006).

Subsequently, we investigated the relationship between the RBP4 mRNA levels in the two fat depots relative to indices of adiposity, including the absolute and relative amount of visceral fat, the magnitude of insulin resistance assessed by euglycemic hyperinsulinemic clamp and other obesity-related metabolic abnormalities (Table 3). No correlations between RBP4 mRNA in the two fat depots and the indices of adiposity, plasma lipids, blood glucose or glucose disposal rate during the clamp were found for the entire group nor for any of the three subgroups. In contrast to our results, Janke et al. (2006) found a down-regulation of RBP4 mRNA in subcutaneous fat in obese women, whereas Tan et al. 
(2007) found an up-regulation of RBP4 mRNA expression in subcutaneous as well as in visceral fat depots in obese insulin-resistant women with polycystic ovary syndrome (PCOS). The differences in the patterns of age, degree of adiposity, body fat distribution, magnitude of insulin sensitivity and in androgenic status (in the study of Tan et al. 2007) could be possible reasons for the discrepancies. In fact, an up-regulation of RBP4 mRNA expression in human adipose tissue explants by 17-beta estradiol and testosterone was demonstrated (Tan et al. 2007).

In the present study, similarly as RBP4, markedly higher values of leptin mRNA levels in subcutaneous compared with visceral fat were found in the three subgroups. For leptin, the most solid data in respect with regional differences in expression are available and the latter finding is in agreement with previous studies (Masuzaki et al. 1995, Montague et al. 1997).

Animal studies suggested a reciprocal relationship between RBP4 and GLUT 4 expression in adipose tissue. In contrast to the studies of Janke et al. (2006) or Tan et al. (2007) no significant correlation was observed between GLUT4 and RBP4 mRNA in subcutaneous adipose tissue $(r=0.078$, NS) while a positive correlation was found in visceral fat $(\mathrm{r}=0.447$, $\mathrm{p}<0.01)$.

Therefore, in spite of obvious limitations of clinical correlative studies, these results suggest that the regulation of RBP4 in humans differs from that in rodents. This is further supported by a recent study (Sell et al. 2007) that reported a positive relationship between RBP4 and GLUT 4 production in adipocytes derived from human mammary adipose tissue.

Recently, Klotig et al. (2007) found higher RBP4 mRNA levels in visceral fat compared with subcutaneous fat. Moreover, the authors found a negative correlation between GLUT4 and RBP4 expression in visceral but not in subcutaneous fat. The reasons of the above mentioned discrepancy between our study and that of Klotig et al. (2007) are difficult to discern, the differences in age range do not appear to be a probable cause. We replicated our RBP4 mRNA and leptin mRNA analysis and confirmed the relationship of leptin mRNA in visceral compared with subcutaneous fat. Our results are in agreement with several previous studies and this supports the reliability of mRNA analysis in the present study. When analyzing the relationships between plasma
RBP4 and indices of adiposity, insulin resistance and metabolic syndrome, we found no differences in plasma RBP4 between the three subgroups (Table 1). Moreover, no significant correlations were found for the entire group or for the subgroups between plasma RBP4 and indices of adiposity, insulin resistance and metabolic syndrome with the exception of a weak positive correlation relative to plasma triglycerides and to blood glucose, which was in agreement with reported results (Erikstrup et al. 2006, Takashima et al. 2006). The absence of a relationship of plasma RBP4 levels in respect to the magnitude of insulin sensitivity is in agreement with several previous studies (Erikstrup et al. 2006, Janke et al. 2006, Broch et al. 2007, Tan et al. 2007) but in contrast to others (Cho et al. 2006, Graham et al. 2006, Balagopal et al. 2007, Haider et al. 2007, Lee et al. 2007). It has to be noted that, in the majority of those studies, insulin sensitivity was not - in contrast to the present study - assessed by euglycemic hyperinsulinemic clamp. In the present study we used a sandwich ELISA assay, which was identical to that showing a high correlation with insulin sensitivity (Graham et al. 2007).

In conclusion, our study demonstrates that RBP4 mRNA expression in visceral fat is low compared to subcutaneous fat regardless of the state of adiposity and the presence/absence of metabolic syndrome. Thus, RBP4 does not appear to be a potential link between visceral adiposity and obesity-related metabolic abnormalities. Additionally, our study failed to confirm a direct relationship between RBP4 adipose tissue expression or RBP4 plasma levels relative to adiposity or insulin sensitivity.

\section{Conflict of Interest}

There is no conflict of interest.

\section{Acknowledgements}

We are grateful to Zuzana Pařízková for her excellent technical assistance and Dr. Zdenka Procházková for laboratory analysis. The authors work was supported by grant IGA NR 8066-3/04 of Ministry of Health of the Czech Republic, INSERM, Research project of Ministry of Education of Czech Republic VZ MŠMT ČR MSM 0021620814 and the project HEPADIP (see http://www.hepadip.org/) supported by the European Commission under the 6th Framework Programme (Contract LSHM-CT-2005-018734). 


\section{References}

ABEL ED, PERONI O, KIM JK, KIM Y-B, BOSS O, HADRO E, MINNEMANN T, SHULMAN GI, KAHN BB: Adipose-selective targeting of the Glut 4 gene impairs insulin action in muscle and liver. Nature 409: 729-733, 2001.

ALBERTI KG, ZIMMET P, SHAW J: The metabolic syndrome - a new worldwide definition. Lancet 366: 1059-1062, 2005.

BALAGOPAL P, GRAHAM TE, KAHN BB, ALTOMARE A, FUNANAGE V, GEORGE D: Reduction of elevated serum retinol binding protein in obese children by lifestyle intervention: association with subclinical inflammation. J Clin Endocrinol Metab 92: 1971-1974, 2007.

BROCH M, VENDRELL J, RICART W, RICHART C, FERNANDEZ-REAL JM: Circulating retinol-binding protein4 , insulin sensitivity, insulin secretion and insulin disposition index in obese and nonobese subjects. Diabetes Care 30: 1802-1806, 2007.

CANCELLO R, TORDJMAN J, PITOU C, GUILHEM G, BOUILLOTY JL, HUGOL D, COUSSIEU C, BASDEVNATY A, BARY HA, BEDOSSA P, GUERRE-MILLO M, CLEMENT K: Increased infiltration of macrophages in omental adipose tissue is associated with marked hepatic lesions in morbid human obesity. Diabetes 55: 1554-1561, 2006.

CHO YM, YOUNG BS, LEE H, LEE N, MIN SS, KWAK SH, LEE HK, PARK KS: Plasma retinol-binding protein-4 concentrations are elevated in human subjects with impaired glucose tolerance and type 2 diabetes. Diabetes Care 29: 2457-2461, 2006.

DEFRONZO RA, TOBIN JD, ANDERS R: Glucose clamp technique: a method for quantifying insulin secretion and resistance. Am J Physiol 237: E214-E223, 1979.

ERIKSTRUP CH., MORTENSEN OH, PEDERSEN BK: Retinol-binding protein 4 and insulin resistance. $N$ Engl $J$ Med 355: 1393-1394, 2006.

FUJIOKA S, MATSUZAWA Y, TOKUNAGA K, TARUI S: Contribution of intra-abdominal fat accumulation to the impairment of glucose and lipid metabolism in human obesity. Metabolism 36: 54-59, 1987.

GARAULET M, MORANTE-HERNANDEZ JJ, LUJAN J, TEBAR FJ, ZAMORA S: Relationship between fat cell size and number and fatty acid composition in adipose tissue from different fat depots in overweight/obese humans. Int J Obes 30: 899-905, 2006.

GRAHAM TE, YANG Q, BLUHER M, HAMMARSTEDT A, CIARALDI TP, HENRY RR, WASON CJ, OBERBACH A, JANSSON PA, SMITH U, KAHN BB: Retinol-binding protein 4 and insulin resistance in lean, obese, and diabetic subjects. N Engl J Med 354: 2552-2563, 2006.

GRAHAM TE, WASON CJ, BLUHER M, KAHN BB: Shortcomings in methodology complicate measurements of serum retinol binding protein (RBP4) in insulin-resistant human subjects. Diabetologia 50: 814-823, 2007.

HAIDER DG, SCHINDLER K, PRAGER G, BOHDJALIAN A, LUGER A, WOLZT M, LUDVIK B: Serum retinolbinding protein 4 is reduced after weight loss in morbidly obese subjects. J Clin Endocrinol Metab. 92: 1168$1171,2007$.

JANKE J, ENGELI S, BOSCHMANN M, ADAMS F, BOHNKE J, LUFT FC, SHARMA AM, JORDAN J: Retinolbinding protein 4 in human obesity. Diabetes 55: 2805-2810, 2006.

KLOTIG N, GRAHAM TE, BERNDT J, KRALISCH S, KOVACS P, WASON CHJ, FASSHAUER M, SCHON M, STUMVOLL M, BLUHER M, KAHN B: Serum retinol-binding protein is more highly expressed in visceral than in subcutaneous adipose tissue and is a marker of intra-abdominal fat mass. Cell Metab 6: 79-87, 2007.

LEE DC, LEE JW, IM JA: Association of serum retinol binding protein 4 and insulin resistance in apparently healthy adolescents. Metabolism 56: 327-331, 2007.

MASUZAKI H, OGAWA Y, ISSE N, SATOH N, OKAZAKI T, SHIGEMOTO M, MORI K, TAMURA N, HOSODA $\mathrm{K}$, YOSHIMASA Y et al.: Human obese gene expression. Adipocyte-specific expression and regional differences in the adipose tissue. Diabetes 44: 855-858, 1995.

MONTAGUE CT, PRINS JB, SANDERS L, DIGBY JE, O'RAHILLY S: Depot- and sex-specific differences in human leptin mRNA expression: implication for the control of regional fat distribution. Diabetes 46: 342-347, 1997. 
SELL H, ECKEL J: Regulation of retinol binding protein 4 production in primary human adipocytes by adiponectin, troglitazone and TNF- $\alpha$. Diabetologia 10: 2221-2223, 2007.

SKURK T, HUBER-ALBERTI C, HERDER C, HAUNER H: Relationship between adipocyte size and adipokine expression and secretion. J Clin Endocrinol Metab 92: 1023-1033, 2007.

TAKASHIMA N, TOMOIKE H, IWAI N: Retinol-binding protein 4 and insulin resistance. $N$ Engl J Med 355: 1392, 2006.

TAN BK, CHEN J, LEHNERT H, KENNEDY R, RANDEVA HS: Raised serum, adipocyte and adipose tissue retinolbinding protein 4 in overweight women with polycystic ovary syndrome: effects of gonadal and adrenal steroids. J Clin Endocrinol Metab 92: 2764-2772, 2007.

TSUTSUMI C, OKUNO M, TANNOUS L, PIANTEDOSI R, ALLAN M, WITT SGD: Retinoids and retinoid-binding protein expression in rat adipocytes. J Biol Chem 267:1805-1810, 1992.

VITKOVA M, KLIMCAKOVA E, KOVACIKOVA M, VALLE C, MORO C, POLAK J, HANACEK J, CAPEL F, VIGUERIE N, RICHTEROVA B, BAJZOVA M, HEJNOVA J, STICH V, LANGIN D: Plasma levels and adipose tissue mRNA expression of retinol-binding protein 4 are reduced during calorie restriction in obese subjects but are not related to diet-induced changes in insulin sensitivity. J Clin Endocrinol Metab 92: 23302335, 2007.

WINKLER G, KISS S, KESZTHELYI L, SAPI Z, ORY I, SALAMON F, KOVACS M, VARGHA P, SZEKERES O, SPEER G, KARADI I, SIKTER M, KASZAS E, DWORAK O, GERO G, CSEH K: Expression of tumor necrosis factor (TNF)- $\alpha$ protein in the subcutaneous and visceral adipose tissue in correlation with adipocyte cell volume, serum TNF- $\alpha$, soluble serum TNF-receptor-2 concentrations and C-peptide level. Eur $J$ Endocrinol 149: 129-135, 2003.

YANG Q, GRAHAM TE, MODY N, PREITNER F, PERONI OD, ZABOLOTNY JM, KOTANI K, OUADRO L, KAHN BB: Serum retinol binding protein 4 contributes to insulin resistance in obesity and type 2 diabetes. Nature 436: 356-362, 2005. 